\title{
長期実測による太陽熱利用天井放射暖房システムの評価 ASSESSMENT OF CEILING RADIATION HEATING SYSTEM USING SOLAR HEAT BASED ON LONG-TERM MEASUREMENT
}

瀬 沼 央 ${ }^{* 1}$, 武田 仁*2

Hiroshi SENUMA and Hitoshi TAKEDA

\begin{abstract}
The ceiling radiation heating system having solar power as a heat source and joint system of air conditioning and floor heating were installed in a highly airtight and adiabatic house. In this report, data obtained from the long-term measurement were analyzed, and comfortableness and energy-saving depending on operating methods (use of air conditioning alone, joint use of air conditioning, panels and floor heating, and use of panels alone) under the same outside air conditions were studied with such figures as COP, PMV and SET*. In addition, it was examined what impact ceiling radiation panels had on indoor thermal environments before and after panels were in operation. The reliance on electric and natural energy was also investigated in order to find how effective the use of solar power was. It has been found that the use of panels alone made the distribution of vertical temperature more uniform than the joint use of panels and air conditioning and that the intermittent use of both panels and air conditioning saved energy and kept indoor environments comfortable. The outcome that the reliance on natural energy stood at between 20 and 40 percent has shown that the use of solar power was effective. It has been discovered that the ceiling radiation system using solar power was more effective than the conventional heating system in terms of energy-saving and comfortableness.
\end{abstract}

Keywords : Radiant Heating, Solar heat, Comfortableness, COP, Long-Term Survey 放射暖房，太陽熱，快適性，COP，長期実測

\section{1. はじめに}

現在、住宅において行われている暖房方式は、電気によるエアコ ン暖房、灯油・ガスによる温風暖房など空気を暖める方式が主流で ある。一方、住宅を中心に普及している床暖房システムなど放射暖 房システムの採用が増加している。筆者らは放射暖房は省エネルギ 一と快適性から有用と考え、太陽熱利用天井放射暖房に注目した。

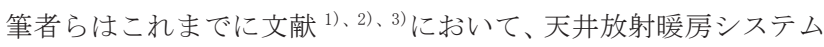
とファンコイルユニットの併用運転、ファンコイルユニットのみ運 転（暖房）および天井放射のみ運転（暖房）の実験室実験の結果報 告を行っている。さらに、宮永ら ${ }^{4)}$ ) による理論解析に関する報告、 李ら ${ }^{6)}$ 、咸ら ${ }^{7)}$ による陽熱を利用した放射床暖房に関寸る報告、 武田ら ${ }^{8)}$ による井水を利用した天井放射冷暖房に関する報告がある 天井放射暖房は、実験室レベルでは室内垂直温度分布が均一になり、 床表面温度が天井放射の影響で上昇する等の快適性向上と省エネル ギー性が確認されている。

本報告においては、熱源に太陽熱を利用した天井放射暖房とエア コン・床暖房の併用システムを高気密高断熱の住宅に導入し、長期 の実測データを解析し、ほぼ等しい外気条件下における運転方法の 違いによる快適性と省エネルギー性をC O P 、 P MV 、 S E T *9) 等 の数值により比較する。さらに、天井放射パネルの室内温熱環境に 及ぼす影響をパネル運転前後で確認する。また、電気エネルギーと 自然エネルギーの依存度を求めて、太陽熱利用の有効性を検証し、 有効利用するための運転方法を検討する。尚、天井パネルを第一と 考え、床暖房は経済性を無視し、計測し易い電気式を選定した。

\section{2. 実験住宅}

実験住宅は、千葉県柏市の敷地面積 $363.4 \mathrm{~m}^{2}$ に建つ木造在来工法 の延床面積 $162.3 \mathrm{~m}^{2}$ で、冷暖房負荷を低減するために、高断熱高気 密 (外壁:グラスウール $100 \mathrm{~mm} 、$ 屋根: ポリスチレン $150 \mathrm{~mm}$ 、床: ポリ スチレン $140 \mathrm{~mm}$ 、開口部: 複層ガラス）となっている（図 1 )。

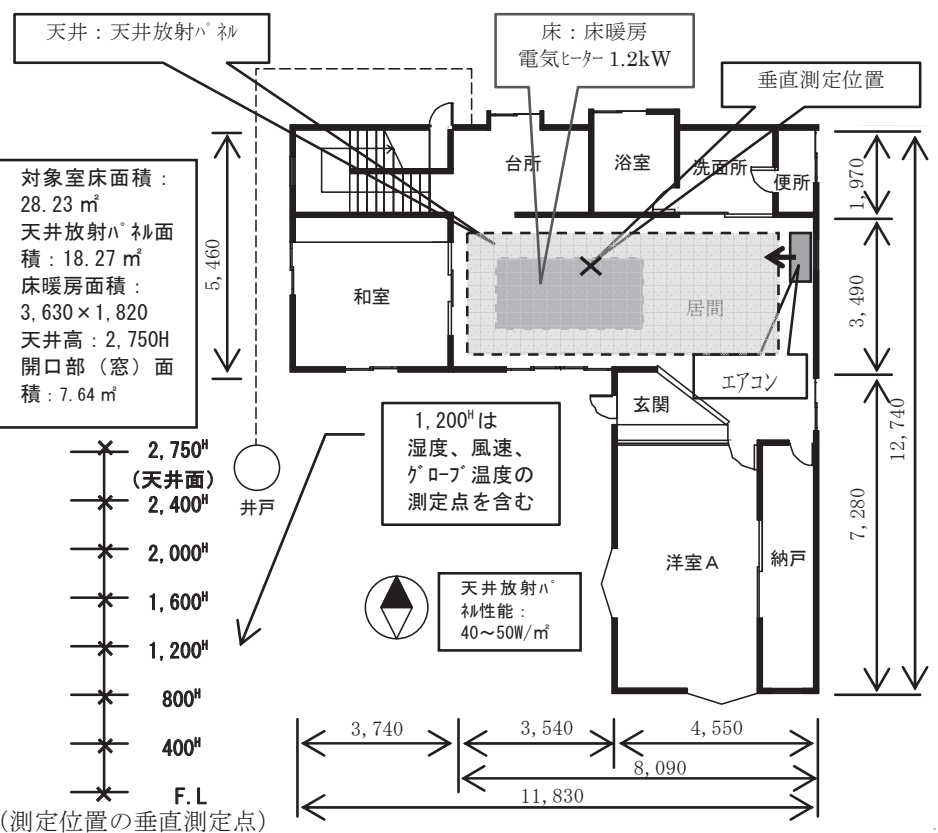

図 1 実験住宅 1 階平面図 (単位：mm)

\footnotetext{
*1 東京理科大学理工学研究科建築学専攻 博士後期課程

*2 東京理科大学理工学部建築学科 教授. 工博

Graduate Student, Dept. of Architecture, Faculty of Science and Technology, Tokyo University of Science

Prof., Dept. of Architecture, Faculty of Science and Technology, Tokyo University of Science, Dr. Eng.
} 


\section{3. 天井放射暖房システム}

\section{1 太陽熱利用システム}

図 2 に天井放射暖房システム系統図 ${ }^{8)}$ を示す。2 階屋根上に設置 された太陽熱集熱器 (平板型、1 重ガラス、選択吸収膜、集熱面積 $\left.2.01 \mathrm{~m}^{2}\right)$ を 10 枚設置し、蓄熱槽（550り）に水を循環させることに より、集熱・蓄熱する。その時、蓄熱槽内下部水温と太陽熱集熱器 の出口水温の温度差を感知し、循環ポンプ (P3) が $0 \mathrm{~N}-\mathrm{OFF}$ 寸る様に なっている。天井放射パネルに温水を供給する時は、蓄熱槽の温水 から熱交換器を介して天井放射パネル系統の循環水に熱を供給して いる。その時、天井放射パネルへの送水温度を一定に保つために送 水温度コントローラにより蓄熱槽系統の 2 方弁を流量制御している。

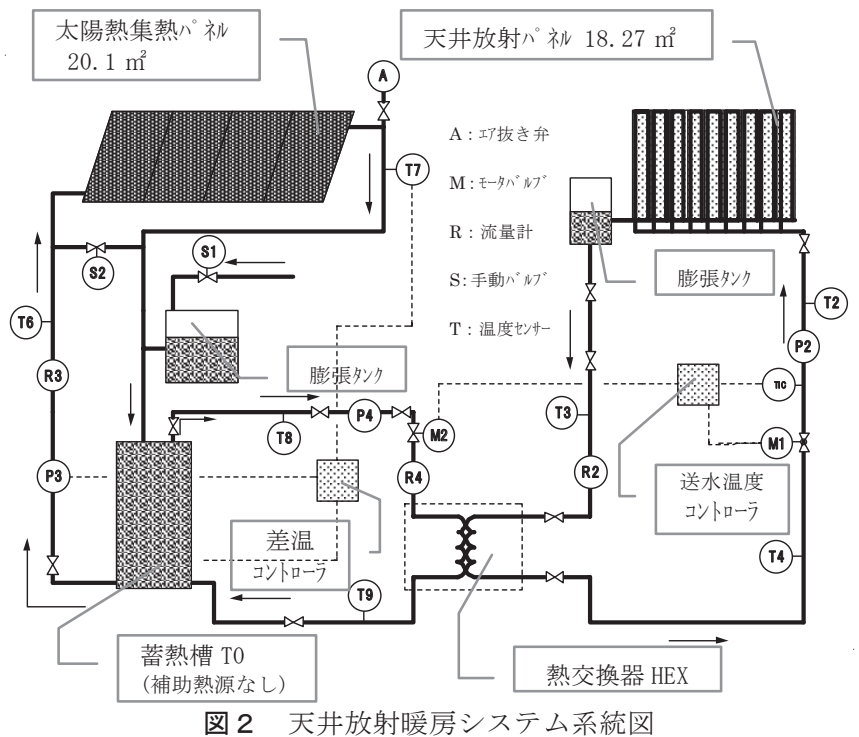

\section{2 天井放射パネル ${ }^{12} 2$}

図 3 に天井放射パネルの断面図を、図 4 に伏図を示す。本体はア ルミの押出し成型板 $(227 \mathrm{~W} \times 2,700 \mathrm{~L})$ で、 $100 \mathrm{~mm}$ 間隔でU字型の 溝があり、外径 $8 \mathrm{~mm}$ の架橋ポリエチレン管をその溝に埋め込み、ア ルミとの熱伝導性を増寸ために特殊キャップ（樹脂製）で押えてい る。パネル裏面には加工した断熱材ポリスチレンがはめ込まれてい る。また設置後、その上にグラスウール $50 \mathrm{~mm}$ を置いて断熱している。

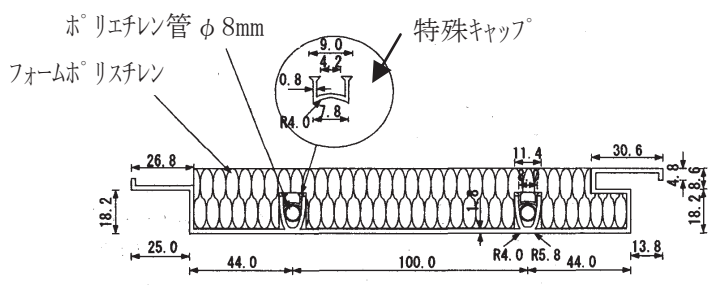

図 3 天井放射パネル断面図

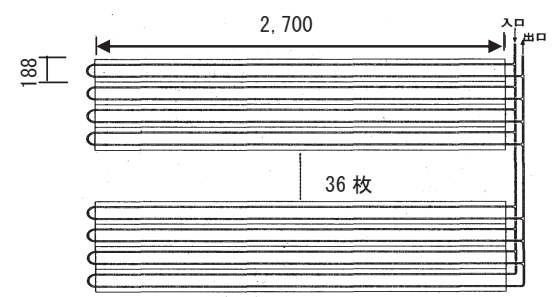

図 4 天井放射パネル伏図
各々の放射パネルの架橋ポリエチレン管は、往きと還りのヘッダ 一に並列に接続されている。

\section{4. 計測システム}

\section{1 測定項目}

各測定ポイントのデータは、 3 秒間隔 2 分間平均值をデータロガ ー（アドバンテストR7430）を介してパソコン（NEC PC-VA80）によ り光ディスク（MO）に長期間連続収録した。

エアコンの風量計測は、エアコンのレターンロに合板でフードを 製作し、接続部から空気が漏孔ないように取り付けて行った。ファ ンがインバータ制御で動いているため、キャリブレーションした風 速計のプローブにより計測し、計測值を平均した数值と開口面積の 積により風量を求めた。尚、風速は事前に多点計測を行い、平均風 速を示す代表点 1 点を選定し、プローブを設置した。

また、吸込み、吹出し空気温度は熱電対にて吸込み 3 点、吹出し 3 点を計測し、それぞれの平均值を空気温度とした。吸込み、吹出 し相対湿度は高分子抵抗式湿度計により吸込み、吹出しのそれぞれ 1 点を計測し、Goff-Gratch の式で重量絶対湿度に変換した（図 5 )。 表 1 に測定項目、測定機器名と型番、精度と測定点数を示す。

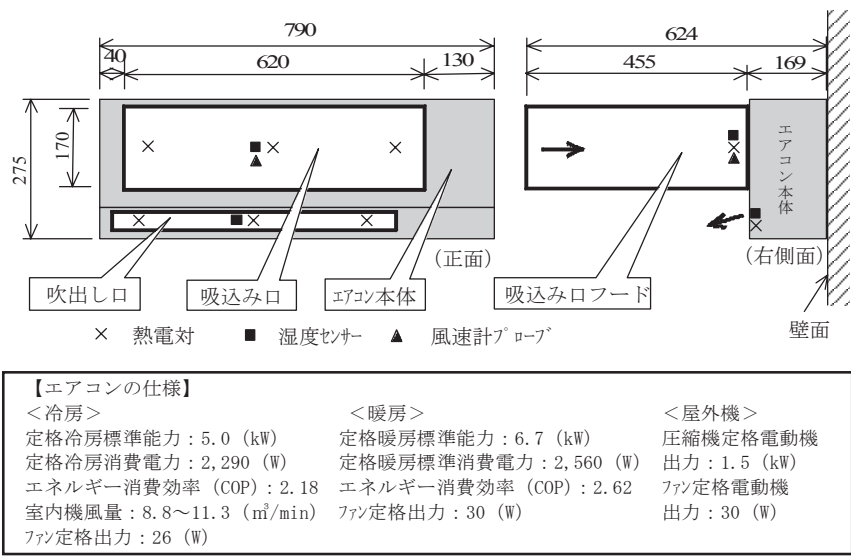

図 5 エアコン周りの測定点とエアコンの仕様

表 1 測定項目と概要

\begin{tabular}{|c|c|c|c|}
\hline 測定項目 & 測定機器名と型番 & 精度 & 点数 \\
\hline 温度 & 熱電対（T-CC 熱電対） & $\pm 0.1^{\circ} \mathrm{C}$ & 45 点 (6) \\
\hline 放射温度 & 放射温度計（MINOLTA：温度計 505） & $\pm 2^{\circ} \mathrm{C}$ & 1 点 \\
\hline 湿度 & 高分子抵抗式湿度計（SHINYEI：THT-B110） & $\pm 3 \%$ & 4台 (2) \\
\hline 風速 & 風速計（ア社双多一風速計：6071） & $\pm 0.1 \mathrm{~m} / \mathrm{s}$ & 2 台 (1) \\
\hline 水平面全天日射量 & 日射計（祆日射計：MS-42） & $\pm 0.3 \%$ & 1台 \\
\hline 流量 & 流量計（加川ッ流量セ洲：ND20） & $\pm 2 \%$ & 3 台 \\
\hline 電力 & トランスデューサ（YOKOGAWA：MODEL2285) & $\pm 0.25 \%$ & 4台 (1) \\
\hline
\end{tabular}

注） 点数の括弧内の数字は、表示点数中のエアコ廻りの測定点数を示す。

\section{2 計算項目と計算方法}

エアコン空気廻り加熱熱量、パネル水廻り加熱熱量、エアコン COP およびパネル COP を下記計算方法にて求める。

（1）エアコン空気廻り加熱熱量 $\mathrm{Q}_{\mathrm{T}}[\mathrm{W}]$

加熱熱量 $Q_{T}=$ 顕熱加熱熱量 $Q_{S}$

$Q_{S}=C_{P} \times \rho \times V \times \Delta t$

$$
=1005 \times 1.2 \times V \times\left(t_{2}-t_{1}\right)
$$




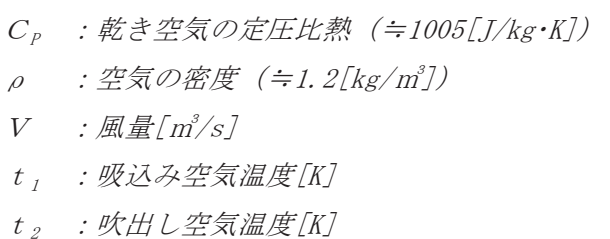

（2）パネル水迴り加熱熱量 $\mathrm{Q}_{\mathrm{P}}[\mathrm{W}]$

$$
\begin{aligned}
Q_{P}= & C_{W} \times R \times \Delta t \\
= & 4.186 \times 10^{3} \times R \times\left(t_{4}-t_{3}\right) \\
& C_{W} \quad: \text { 水の比熱 }\left(\fallingdotseq 4.186 \times 10^{3}[\mathrm{~J} / \mathrm{kg} \cdot \mathrm{K}]\right) \\
& R \quad: \text { パネルの循環流量 }[\mathrm{kg} / \mathrm{s}] \\
& t_{3} \quad: \text { パネルの還水温度 }[\mathrm{K}] \\
& t_{4} \quad: \text { パネルの送水温度 }[\mathrm{K}]
\end{aligned}
$$

（3） COP（成績係数）

$$
\begin{aligned}
& \text { エアコン } C O P=\text { エアコン加熱熱量 }[W] / \text { エアコン消費電力 }[W] \quad \cdots \cdots(3) \\
& \text { パネル } C O P=\text { パ礼加熱熱量 }[W] /(\text { 集熱 }+ \text { 循環ポンプ消費電力) }[W] \cdots(4)
\end{aligned}
$$

5. 天井放射暖房とエアコン、床暖房の組合せ運転

\section{1 実験概要}

2004 年 12 月 1 日から 2005 年 2 月 28 日、 2005 年 12 月 1 日から 2006 年 2 月 28 日の暖房期間において、天井放射パネル（送水温度 $35 \sim 40^{\circ} \mathrm{C}$ 、以下パネルと呼ぶ)、床暖房 $\left(6.6 \mathrm{~m}^{2}\right.$ 電気ヒーター $\left.1,200 \mathrm{~W}\right)$ およびエアコン（暖房）運転を連続して行なった。それぞれの制御

\begin{tabular}{|c|c|c|c|c|c|}
\hline \multirow{2}{*}{\multicolumn{2}{|c|}{ 期 問 }} & 2004 年度 & \multicolumn{3}{|c|}{2005 年度 } \\
\hline & & $12 / 1 \sim 2 / 28$ & $12 / 1 \sim 28$ & $1 / 1 \sim 2 / 4$ & $2 / 11 \sim 28$ \\
\hline \multirow{3}{*}{$\begin{array}{l}\text { 設定 } \\
\text { 温度 } \\
\left({ }^{\circ} \mathrm{C}\right)\end{array}$} & 埇コ暖房 (宝温价バータ) & 22 & 21 & 21 & 21 \\
\hline & 床暖房 (室温 ON-OFF) & 22 & 23 & 22 & 22 \\
\hline & べ礼暖房（室温 ON-OFF） & 22 & 22 & 22 & 23 \\
\hline
\end{tabular}
は独立している。エアコンは、居住者（夫婦）の意思で運転を行な い、居間を使用しない時間（深夜及び外出時など）は、照明やテレ ビ等の家電製品の電源を $0 \mathrm{FF}$ とした。いずれも電力使用状況は、卜 ランスデューサを介しデータロガーに収録した。なお、隣室および 2 階は非空調とした。2004 年度の各運転状況を図 6 に、2005 年度を 図 7 に示す。また、各運転方式の設定温度と制御方法を表 2 に示寸。

表 2 各運転方法の期間別設定温度と制御方法 (括弧内は制御方式)

\section{2 短期実測結果}

（1）ほぼ等しい外気条件下における各運転パターンの比較

各方式の比較のために、外気温度と日射量の日変化が比較的類似 した近接する 3 日間を選定した。

図 $8 \sim 10$ に 2006 年 2 月 $22 、 23 、 25$ 日の外気温度と水平面全天日 射量の 24 時間の日変化を示寸。

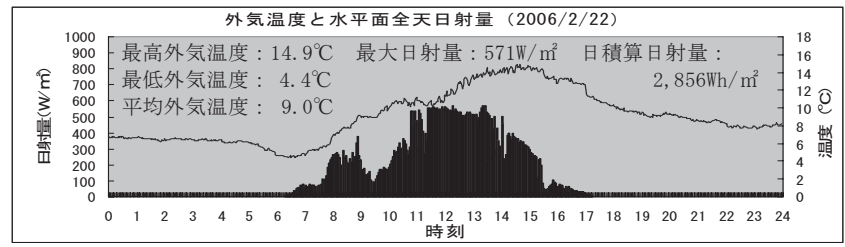

図 8 外気温度と水平面全天日射量の日変化

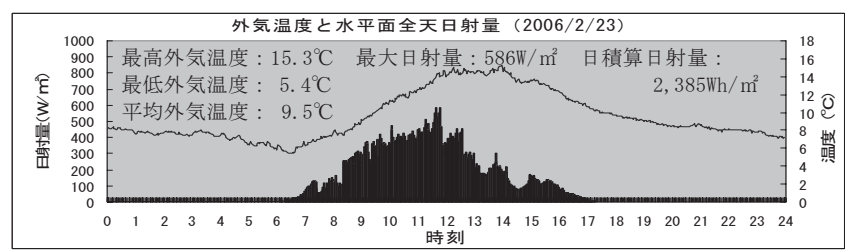

図 9 外気温度と水平面全天日射量の日変化

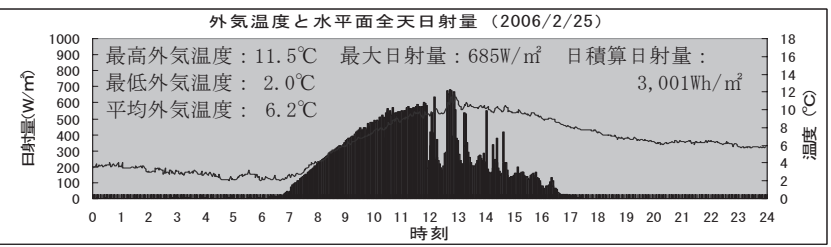

図 10 外気温度と水平面全天日射量の日変化

3 日間の外気温度と水平面全日射量がほぼ等しいため、外気負荷 条件が等しい日と考え、それぞれ同時間帯（21:00～22:00）に2月 22 日が床暖房 + エアコン運転、 2 月 23 日がパネル + 床暖房 + エア コン運転、2月 25 日がパネルのみ運転が行なわれているので、それ ぞれの加熱熱量、電力量、CO P 、室内温湿度、P MV S S T * 等を求め、性質の違う各暖房方式がエネルギー消費と効率や室内環 境に与える影響について比較検討を行う。尚、2/25 は 2 シーズン中 最も選定条件に合うが、外気温度が他の 2 日よりも $3{ }^{\circ} \mathrm{C}$ 程度高い。

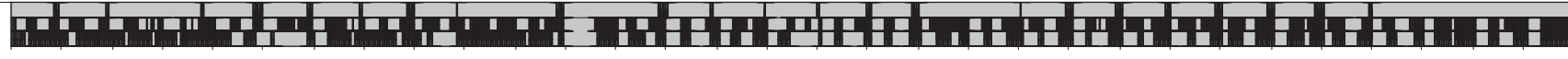

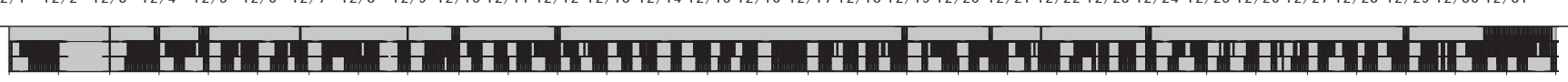
\#HAH 図 6 エアコン、床暖房とパネルの運転状況（上から 2004/12/1３1、2005/1/1３1、2/1～28）上段：パ礼 中段：床暖房 下段：エアコン

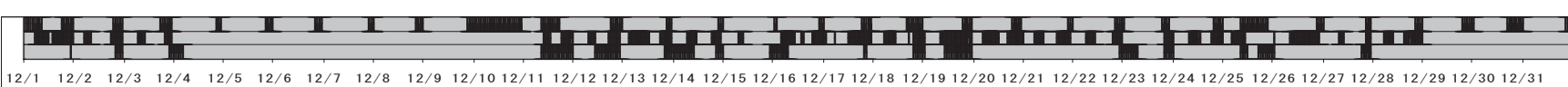

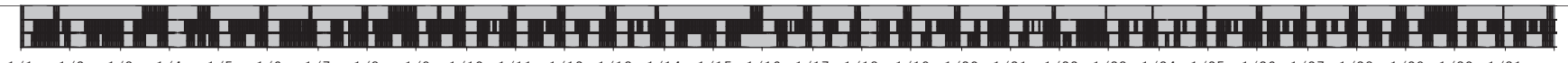

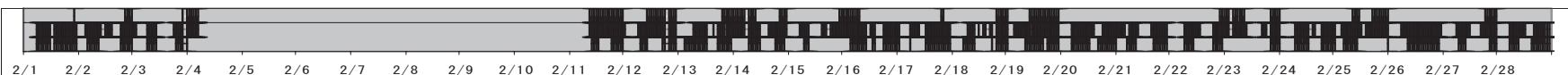

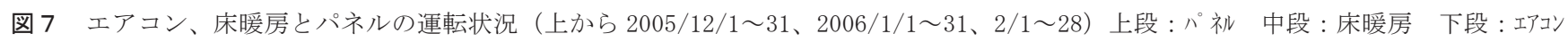


i ) 加熱熱量

図 11〜 13 に 2 月 $22 、 23 、 25$ 日の加熱熱量の日変化を示す。

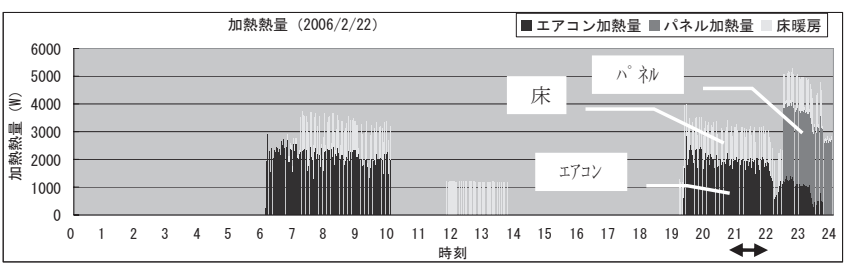

図 11 加熱熱量の日変化（床暖房十エアコン運転 21:00～22:00）

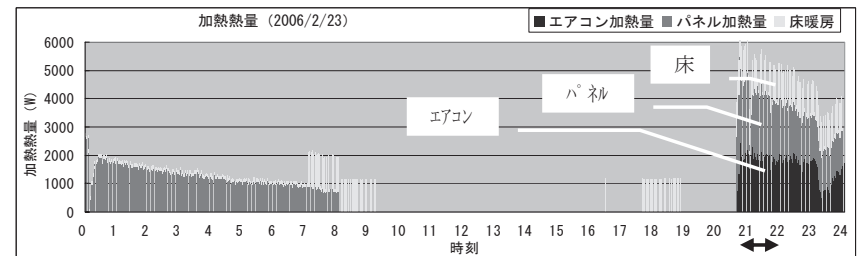

図 12 加熱熱量の日変化 (パ祙+床暖房十エアコン運転 21:00〜22:00)

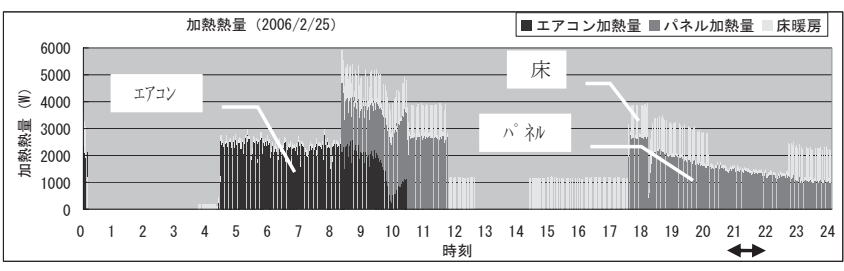

図 13 加熱熱量の日変化（パ祙み運転 21:00〜 22:00）

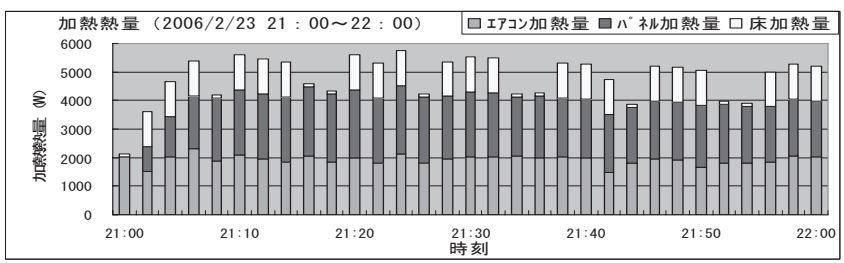

図 14 加熱量の時刻変化（パ祀十床暖房十エアコン運転、21:00〜22:00)

2 月 $22 、 23 、 25$ 日の 21 時から 22 時の運転状態が、それぞれ床暖 房十エアコン運転、パネル十床暖房＋エアコン運転、パネルのみ運 転であるので、それを同外気条件下での比較対象データとして解析 する。

図 14 に 2 月 23 日の 21 時から 22 時の加熱熱量の時刻変化の詳細 を示す。エアコン暖房、パネル暖房、床暖房が同時に行われている のが分かる。

ii ) 電力量

図 15〜17 に 2 月 $22 、 23 、 25$ 日の電力量の日変化を示す。

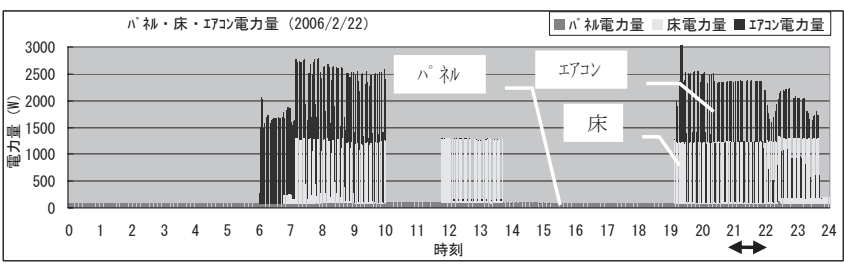

図 15 電力量の日変化 $(2006 / 2 / 22$ の床暖房十エアコン運転 $)$

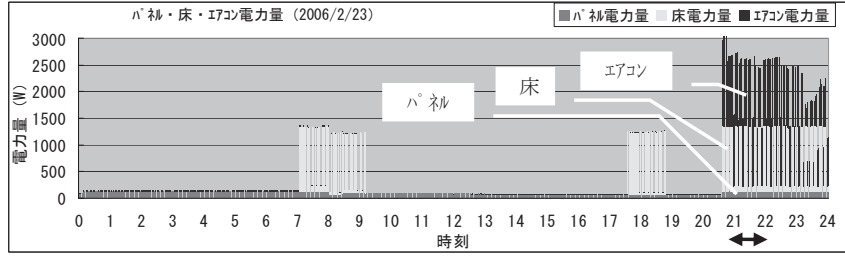

図 16 電力量の日変化 $(2006 / 2 / 23$ のパ 祃十床暖房エエアコン運転 $)$

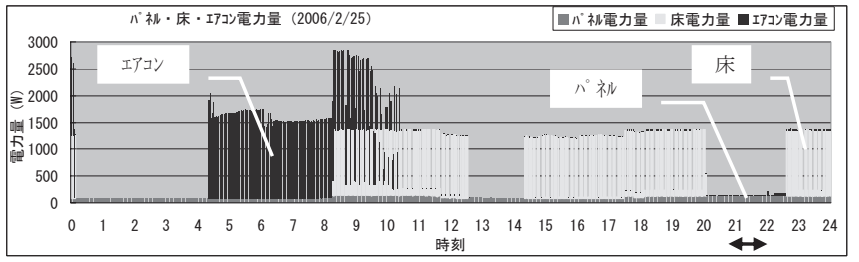

図 17 電力量の日変化 $(2006 / 2 / 25$ のパ祅のみ運転 $)$

パネルは循環ポンプ(図 2 中の $\mathrm{P} 2+\mathrm{P} 3+\mathrm{P} 4$ )の電力量が 24 時間低 い值で推移している。エアコンは圧縮機の $0 \mathrm{~N}-0 \mathrm{FF}$ により電力量が発 生している。床は発熱抵抗体への電流の $0 \mathrm{~N}-\mathrm{OFF} に よ り$ 電力量が発生 している。パネルの電力量だけが i )の加熱熱量と比例していない。

\section{iii）室内温度}

図 18 に2 月2 $23 、 25$ 日の室内温度の日変化を示す。

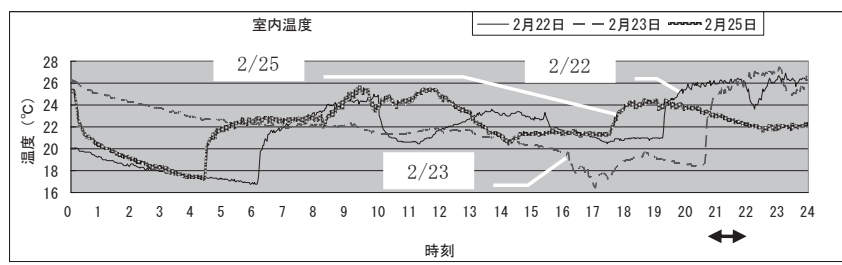

図 18 室内温度の日変化（2006/2/22、23、25）

2 月 $22 、 23$ 日の $21 \sim 22$ 時の床暖房十エアコン暖房とパネル十床 暖房十エアコン暖房は室温が $26^{\circ} \mathrm{C}$ と高く、2月 25 日のパネルのみ 運転は室温が 22 $23^{\circ} \mathrm{C}$ と低くなっている。これは、外気温度が 2 。 $3{ }^{\circ} \mathrm{C}$ 程度低いためと思われる（図 8～10 参照）。

iv）室内相対湿度

図 19 に 2 月 $22 、 23 、 25$ 日の室内相対湿度の日変化を示す。

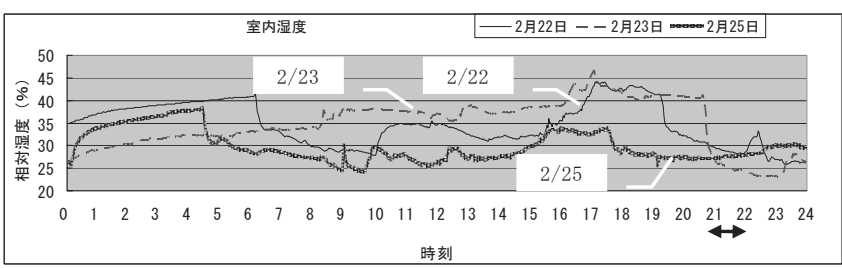

図 19 室内相対湿度の日変化 $(2006 / 2 / 22 、 23 、 24)$

21〜22 時の相対湿度は、 2 月 23 日のパネル十床暖房十エアコン 暖房が $25 \%$ 程度と最も低くなっている。 


\section{v) $\mathrm{PMV}$}

図 20 に 2 月 $22 、 23 、 25$ 日の室内の P MVの日変化を示す。 $2 / 25$ が 21:00〜22:00 で最も低いのは、外気温度の影響と思われる。

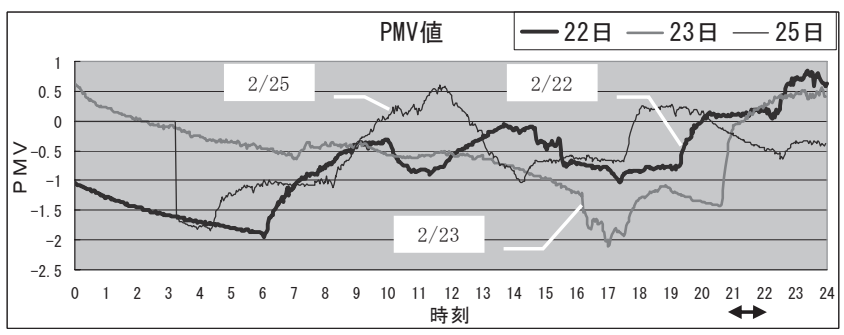

図 $20 \mathrm{PMV}$ の日変化 $(2006 / 2 / 22 、 23 、 25)$ (clo 值：1.0、met 值：1.0)

加熱量の無い 2 月 22 日の $0 \sim 6$ 時、14〜19 時、 2 月 23 日の $9 \sim$ 21 時、 2 月 25 日の $0 \sim 5$ 時、13〜18 時が低い值を示している。

vi）垂直温度分布

床暖房エエアコン（2006 年 2 月 22 日）、パネル十床暖房エエアコ ン (2006 年 2 月 23 日)、パネルのみ（2006 年 2 月 25 日）運転時の 室内垂直温度分布を図 21 に示す。

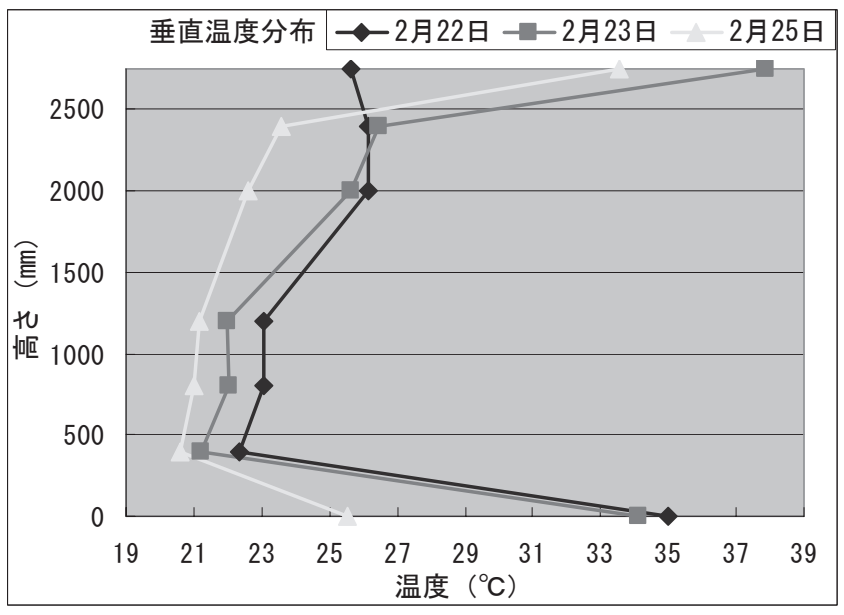

図 21 室内垂直温度分布

（2）天井パネルーの通水前後の状況（2月 22 日 18:00 24:00）

図 22 に 2 月 22 日の 18:00〜 24:00の運転状況を示す。19 時過ぎ に床暖房とエアコンがほぼ同時に稼動し、併用運転をしている。 $21: 58$ 頃エアコンが能力を下げはじめ、22:26 頃天井パネルが稼動を し、23:42 頃までエアコン、床暖房、天井パネルの併用運転が行わ れた。

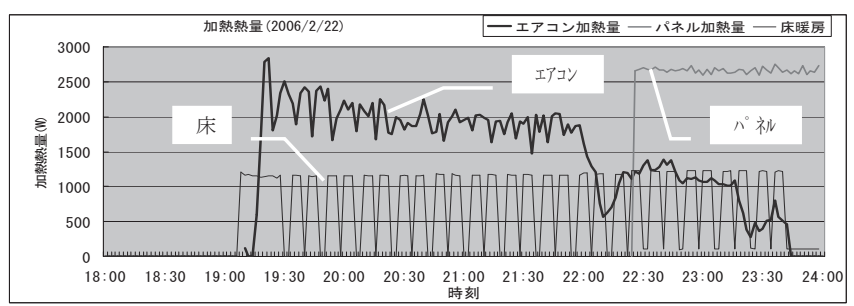

図 22 エアコン、床暖房、パネルの加熱熱量の時刻変化

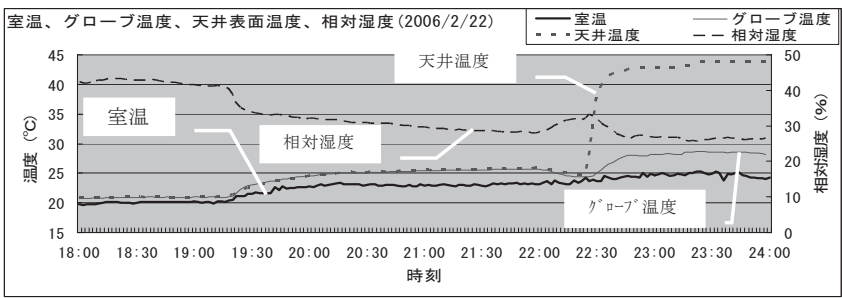

図 23 室温・グローブ温度・天井表面温度・相対湿度の時刻変化

図 23 に室温、グローブ温度、天井表面温度、相対湿度の時刻変化 を示す。 $20^{\circ} \mathrm{C}$ 程度であった室温が、エアコン十床暖房により $23^{\circ} \mathrm{C}$ 程 度まで上昇した。また、グローブ温度も室温 $+2{ }^{\circ} \mathrm{C}$ 程度に上昇した。 相対湿度は、室温の上昇に伴い下っている。

さらに、22:26 頃天井パネルが稼動するとパネル表面温度が急激 に上昇し、それに伴いグローブ温度も上昇している。エアコン十床

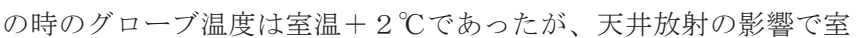
温 $+4{ }^{\circ} \mathrm{C}$ 程度に差が大きくなっている。

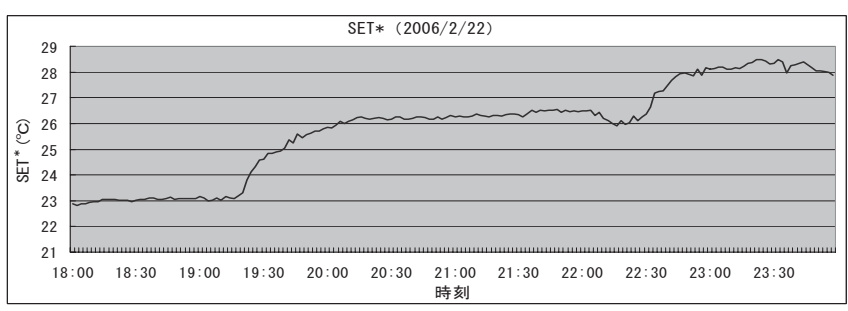

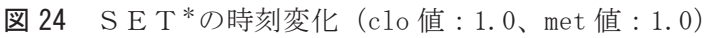

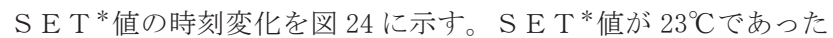
ものがエアコン十床の稼動により $26^{\circ} \mathrm{C}$ となり、エアコン十床十パネ ルの稼動で $28^{\circ} \mathrm{C}$ ま卡昇している。

\section{3 長期実測結果}

2004 年 12 月 1 日 2005 年 2 月 28 日（以下 2004 年度とする）と 2005 年 12 月 1 日〜 2006 年 2 月 28 日（以下 2005 年度とする）の冬 期 2 シーズンのデータから下記の内容の解析を行った。

(1) 太陽熱集熱量の長期変化。

図 25 に 2004 年度、図 31 に 2005 年度のグラフを示す。

(2) 天井パネル、床暖房、エアコンの加熱量の長期変化。 図 26 に 2004 年度、図 32 に 2005 年度のグラフを示す。

(3) 天井パネル、床暖房、エアコンの暖房寄与率の長期変化。 図 27 に 2004 年度、図 33 に 2005 年度のグラフを示す。

(4) 太陽熱集熱量と放熱量（天井パネル）の長期変化。 図 28 に 2004 年度、図 34 に 2005 年度のグラフを示す。

(5) 室内側放熱量をエアコン放熱量と放射暖房放熱量（天井パネ ル十床暖房）に分け、放射を全て太陽熱でまかなった場合の 太陽熱集熱量と放射暖房放熱量の割合の長期変化。 図 29 に 2004 年度、図 35 に 2005 年度のグラフを示す。

(6) エアコン十床暖房の加熱量を電気エネルギー依存熱量、パネ ルの加熱量を自然エネルギー依存熱量とし、合計を $100 \%$ と した時のそれぞれの割合の長期変化。

図 30 に 2004 年度、図 36 に 2005 年度のグラフを示す。 


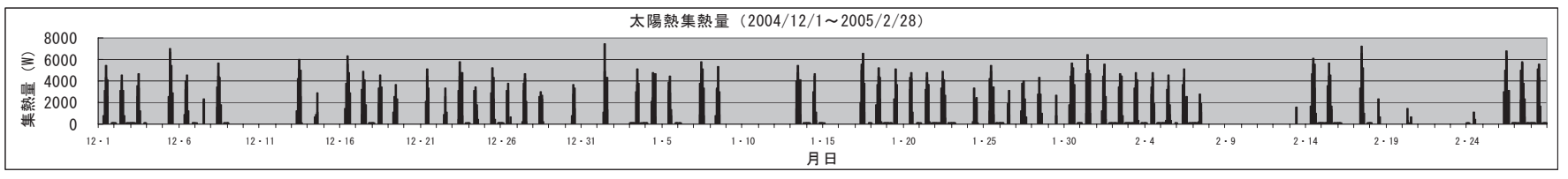

図 25 太陽熱集熱量の長期変化（2004/12/1～2005/2/28）

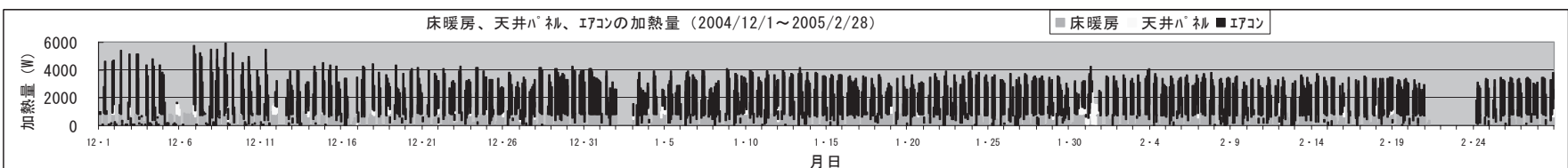

図 26 床暖房、天井パネル、エアコンの加熱量の長期変化（2004/12/1～2005/2/28）

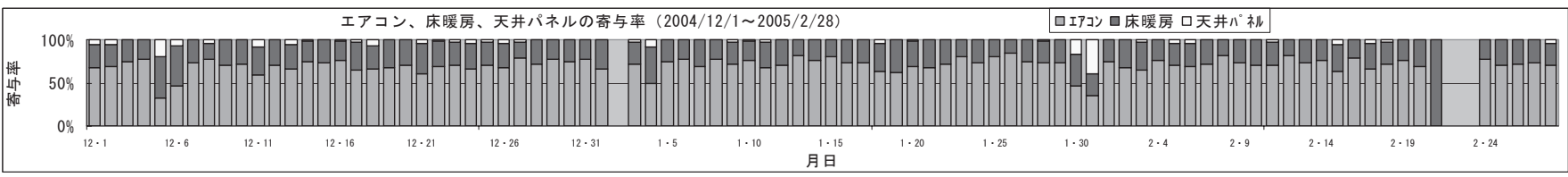

図 27 エアコン、床暖房、天井パネルの暖房寄与率の長期変化 $(2004 / 12 / 1$ 2005/2/28)

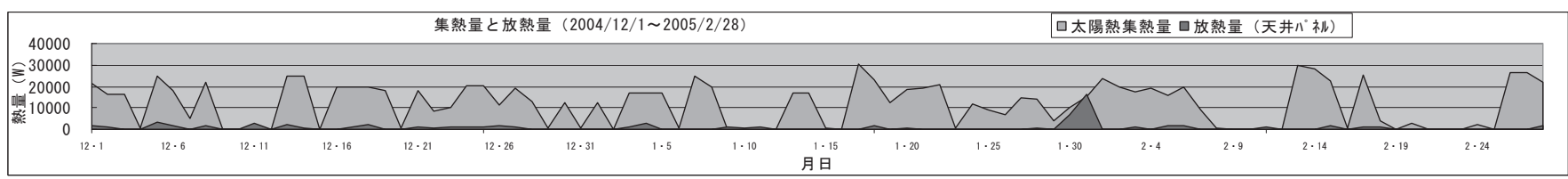

図 28 集熱量と放熱量（天井パネル）の長期変化（2004/12/1～2005/2/28）

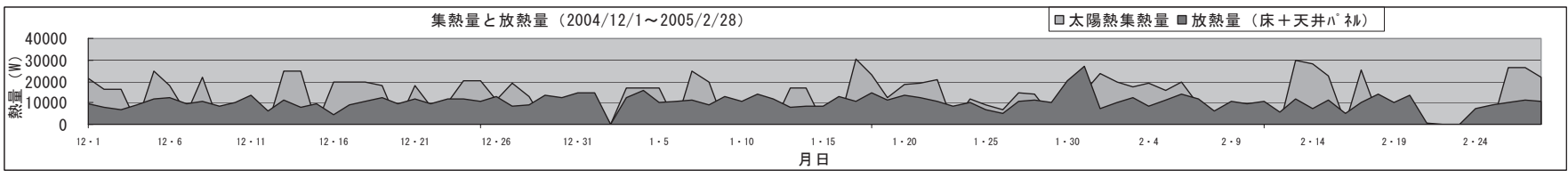

図 29 集熱量と放熱量（天井パネル十床暖房）の長期変化（2004/12/1～2005/2/28）

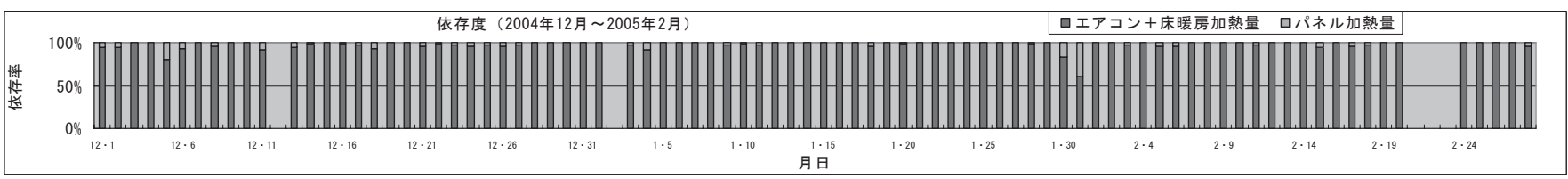

図 30 電気エネルギー依存熱量と自然エネルギー依存熱量の比率の長期変化（2004/12/1～2005/2/28）(12月 12 日、1月 2 日、2月 21〜23 日は欠測)

(2) $2005 / 12 / 1 \sim 2006 / 2 / 28$ の測定結果

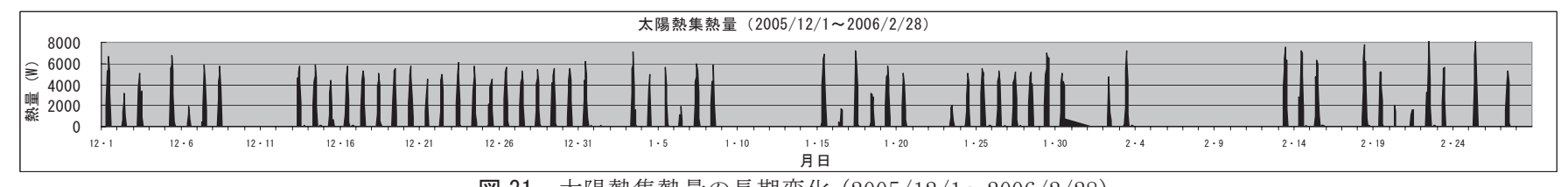

図 31 太陽熱集熱量の長期変化 $(2005 / 12 / 1 \sim 2006 / 2 / 28)$

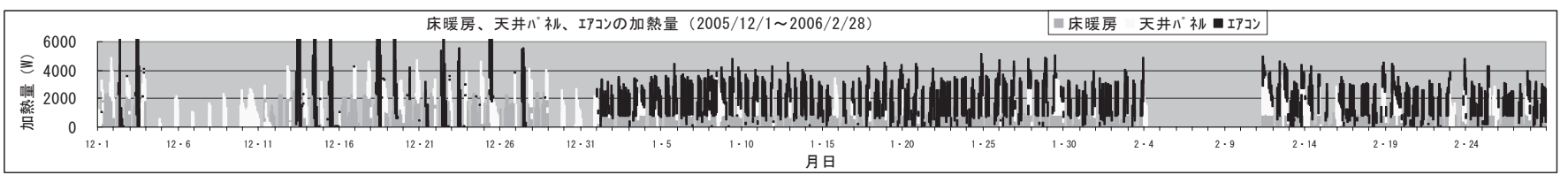

図 32 床暖房、天井パネル、エアコンの加熱量の長期変化 $(2005 / 12 / 1 \sim 2006 / 2 / 28)$

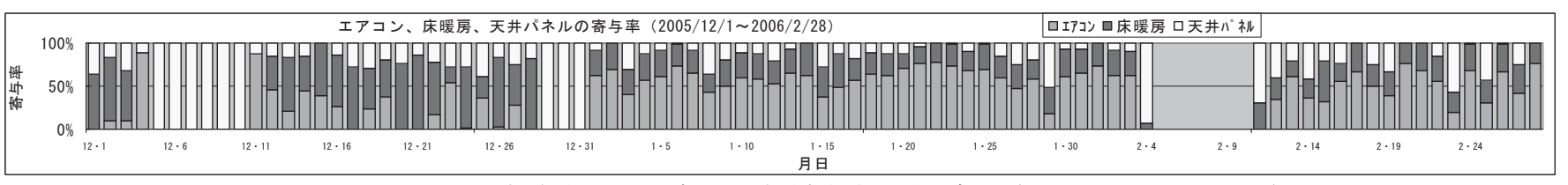

図 33 エアコン、床暖房、天井パネルの暖房寄与率の長期変化（2005/12/1～2006/2/28） 


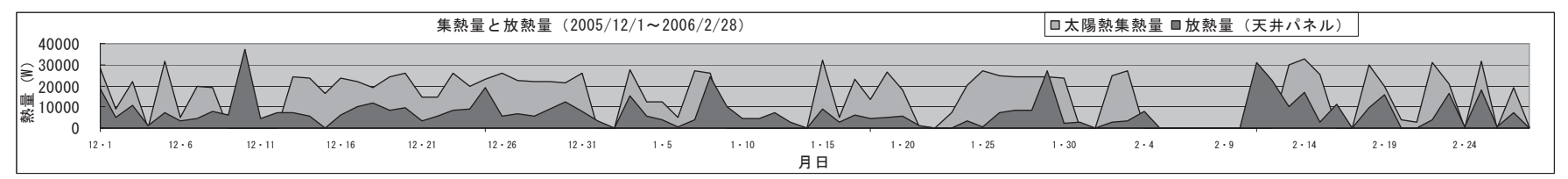

図 34 集熱量と放熱量（天井パネル）の長期変化（2005/12/1 2006/2/28）

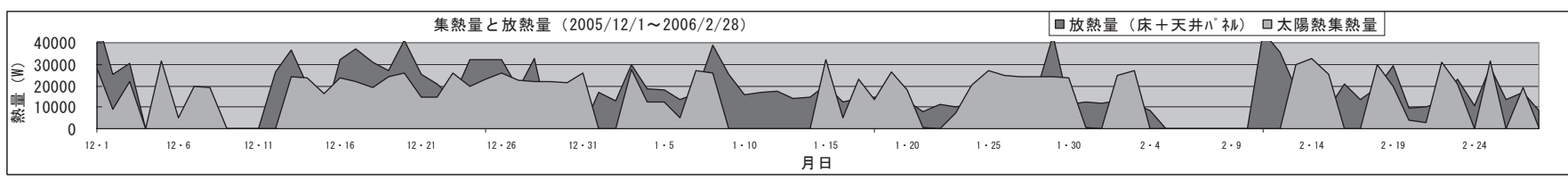

図 35 集熱量と放熱量（天井パネル十床暖房）の長期変化（2005/12/1～2006/2/28）

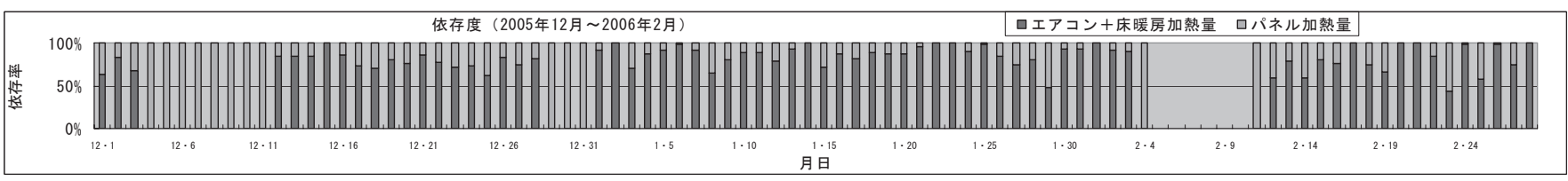

図 36 電気エネルギー依存熱量と自然エネルギー依存熱量の比率の長期変化（2005/12/1～2006/2/28）（12月 4 11日、29〜31 日、2月 4 11 日は欠測)

\section{6. 考察}

\section{1 短期計測結果}

床暖房＋エアコン、パネル十床暖房＋エアコン、パネルのみ運転 の 3 パターンにおける加熱熱量、電力量、C O P 、室内温湿度、グ ローブ温度、グローブ温度一室温、PMVの比較を表 3 に示す。気 流は、いずれも $0.1 \mathrm{~m} / \mathrm{sec}$ 以下であり、気流による P MV・S E T* への影響はない。

表 3 各運転パターンの比較 $(21: 00 \sim 22: 00$ の平均值)

\begin{tabular}{|c|c|c|c|c|}
\hline & & $\begin{array}{c}\text { 床暖房 } \\
+ \text { +エコン }\end{array}$ & $\begin{array}{c}\text { パネル } \\
\text { +床暖房 } \\
\text { +エアコン }\end{array}$ & $\begin{array}{c}\text { パネル } \\
\text { のみ }\end{array}$ \\
\hline \multirow{4}{*}{ 加熱熱量 (Wh) } & パ视 & - & 2,087 & 1,365 \\
\hline & 床 & 1,167 & 849 & - \\
\hline & エアコン & 1,887 & 1,922 & - \\
\hline & 合計 & 3,054 & 4,858 & 1,365 \\
\hline \multirow{4}{*}{ 電力量（Wh） } & 八゚视 & - & 125 & 126 \\
\hline & 床 & 1,167 & 849 & - \\
\hline & エアコン & 1,122 & 1,229 & - \\
\hline & 合計 & 2,289 & 2,203 & 126 \\
\hline \multirow{3}{*}{$\mathrm{COP}$} & パ礼 & - & 16.1 & 10.8 \\
\hline & 床 & 1.0 & 1.0 & - \\
\hline & エアコン & 1.7 & 1.6 & - \\
\hline 室温（ $\left.{ }^{\circ} \mathrm{C}\right)$ & & 23.1 & 22.0 & 21.2 \\
\hline 相対湿度（\%) & & 28.7 & 25.3 & 27.5 \\
\hline グロ 泾温度 ( $\left.{ }^{\circ} \mathrm{C}\right)$ & & 25.6 & 26.6 & 24.0 \\
\hline PMV & & 0.14 & 0.08 & -0.35 \\
\hline
\end{tabular}

(c1o 值: 1.0 met 值: 1.0 )

（1）加熱熱量に関しては、パネル十床暖房エエアコン運転の加熱熱 量合計が 4,858Wh と最も大きいのは、8:00 頃から 20:40 頃まで床暖 房が 2 時間程度稼動しただけで、パネルとエアコンは停止状態であ ったため、暖房立上り時に大きい加熱熱量になったと考えられる。 また、パネル加熱量がパネルのみの時に $1,365 \mathrm{Wh}$ と小さいのは、 14:15 頃から床暖房が稼動し、さらに 17:30 頃からパネルも稼動し ていたため、室内設定温度を一定に保つための加熱熱量が減少した ものと考えられる（図 12、13 参照)。
（2）加熱熱量と電力量から求めた C O P に関して、床暖房十エアコ ン運転時は床暖房が 1.0、エアコンが 1.7、パネル十床暖房エエアコ ン運転時もそれぞれ 1.0 と 1.6 であり、運転パターンによって大き な違いはない。パネルの C O P は、パネル十床暖房エエアコン運転 時が 16.1 、パネルのみ運転時が 10.8 と高い值となっているが、電 力量が常に一定であるため、負荷の大きな時の方が C O P が大きく なることが分かる。

（3）相対湿度に関しては、25～29\%と運転パターンの違いによる差 は認められない。

（4）PMVに関しては、床暖房＋エアコン運転が 0.14、パネル+ 床暖房十エアコン運転が 0.08 、パネルのみ運転が- 0.35 と何れも快 適範囲に入っている。床暖房十エアコン運転とパネル + 床暖房 + エ アコン運転を比較すると、室温が $23.1^{\circ} \mathrm{C}$ と $22.0^{\circ} \mathrm{C}$ で床暖房十エアコ ン運転が高いが、グローブ温度は $25.6^{\circ} \mathrm{C}$ と $26.6^{\circ} \mathrm{C}$ で床暖房十エアコ ン運転が低くなっている。そこで、表 4 に示寸様に床暖房十エアコ ンの室温、相対湿度、グローブ温度はそのままとし、パネル十床暖 房十エアコン運転の室温はそのままで、相対湿度とグローブ温度を 床暖房十エアコン運転のそれと同じにした場合のパネル十床暖房 + エアコン運転の P MVを算出すると-0.03 となる。これにより、 $\mathrm{P}$ MVが 0.08 を得られたことは、床暖房十パネルの放射の影響が現れ ているものと考えられる。また、パネルのみの場合は P MVが-0. 35 であるが、同じ $21.2^{\circ} \mathrm{C}$ の室温でパネル放射の影響がないグローブ温 度を $21.2^{\circ} \mathrm{C}$ にした場合、P MVは-0. 68 となり、快適範囲から寒い 方に移行する。したがって、室温 $21.2^{\circ} \mathrm{C}$ であってもパネル放射の影 響で快適範囲に保たれていることが分かる。

表 4 P MVの予測值による比較

\begin{tabular}{|l||c|c|c|}
\hline & $\begin{array}{c}\text { 床暖房 } \\
\text { +エアコン }\end{array}$ & $\begin{array}{c}\text { パネル十床暖房 } \\
\text { エアコン }\end{array}$ & パネルのみ \\
\hline \hline 室温 $\left({ }^{\circ} \mathrm{C}\right)$ & 23.1 & 22.0 & 21.2 \\
\hline 相対湿度 $(\%)$ & 28.7 & $(28.7)$ & 27.5 \\
\hline グローブ温度 $\left({ }^{\circ} \mathrm{C}\right)$ & 25.6 & $(25.6)$ & $(21.2)$ \\
\hline $\mathrm{PMV}$ & 0.14 & $(-0.03)$ & $(-0.68)$ \\
\hline
\end{tabular}

(c1o 值 : 1.0 met 值 : 1.0$)$ 
（5）垂直温度分布に関しては、過去の実験室での計測データ ${ }^{3)}$ と同 様にエアコンが併用で稼動している時は温かい軽い空気が上昇し、 上下の温度差が大きくなるが、パネルのみ運転の場合は上下温度差 が小さくなり、床上 $500 \mathrm{~mm}$ の点で約 $2{ }^{\circ} \mathrm{C}$ 差があり、床上 $2,000 \mathrm{~mm}$ の点では約 $4{ }^{\circ} \mathrm{C}$ 差になっている (図 21 参照)。

\section{2 長期計測結果}

2004 年 12 月 1 日 2005 年 2 月 28 日の太陽熱集熱量の長期変化の グラフによると、集熱量は 4,000〜6,000（W） $\left(200 ３ 00 \mathrm{~W} / \mathrm{m}^{2} ）\right.$ の瞬 時值を示している (図 25 参照)。室内暖房負荷に対してェアコン、床 暖房、天井パネルにより熱が供給されているが、それぞれの加熱量 と寄与率から約 70\%をエアコンが、残りの約 30\%を放射暖房である 床暖房と天井パネルが受け持っていることが分かる(図 27 参照)。

2005 年 12 月 1 日 2006 年 2 月 28 日の太陽熱集熱量の長期変化の グラフによると、集熱量は前年より多少多いが 4,000〜 6, 000 (W) の瞬時值を示している(図 31 参照)。エアコン、床暖房、天井パネル の寄与率は、12月 1～28 日ではエアコン暖房が 0～50\%、放射暖房 (床暖房十天井パネル) が 46〜 100\%、1月 1 日〜2月 4 日ではそれ ぞれ 18〜 78\%、22〜82\%、2 月 11〜28 日ではそれぞれ 20〜 77\%、 23〜80\%を示しており、期間により違いがある(図 33 参照)。さらに、 自然エネルギー依存率は 2004 年度が平均約 2. 9\%であったが、2005 年度は平均約 $23 \%$ に増加している。これは、エアコンの設定温度を パネルの設定温度よりも下げたためと考えられ(図 30、36 参照)、工 アコンが設定温度に達し停止してもパネルは稼動するためである。

表 5 に 2004 年度と 2005 年度のエアコン暖房と放射暖房（床暖房 十パネル暖房）の寄与率および自然エネルギー依存率とその時のエ アコン暖房、床暖房、パネル暖房の設定温度を示す。各暖房方式の 設定温度の違いが寄与率に大きく影響している。

表 5 寄与率と設定温度

\begin{tabular}{|c|c|c|c|c|c|}
\hline \multirow{2}{*}{ 期 } & \multirow{2}{*}{ 間 } & 2004 年度 & \multicolumn{3}{|c|}{2005 年度 } \\
\hline & & $12 / 1 \sim 2 / 28$ & $12 / 1 \sim 28$ & $1 / 1 \sim 2 / 4$ & $2 / 11 \sim 28$ \\
\hline \multicolumn{2}{|c|}{ エアコン寄与率（\%) } & $32 \sim 84(70)$ & $0 \sim 54(20)$ & $18 \sim 78(60)$ & $20 \sim 77(52)$ \\
\hline \multicolumn{2}{|c|}{ 放射暖房寄与率（\%） } & $16 \sim 68(30)$ & $46 \sim 100(80)$ & $22 \sim 82(40)$ & $23 \sim 80(48)$ \\
\hline \multicolumn{2}{|c|}{ 自然工神性一依存率 (\%) } & (2.9) & $(22.9)$ & $(13.9)$ & $(23.0)$ \\
\hline \multirow{3}{*}{$\begin{array}{c}\text { 設定温度 } \\
\left({ }^{\circ} \mathrm{C}\right)\end{array}$} & Iアュ】暖房 & 22 & 21 & 21 & 21 \\
\hline & 床暖房 & 22 & 23 & 22 & 22 \\
\hline & $n$ “祌暖房 & 22 & 22 & 22 & 23 \\
\hline
\end{tabular}

注）括弧内の数字は平均值を示寸。

\section{7.まとめ}

エアコン十床暖房と天井放射暖房併用の実物件導入時の運転状況 の検証と自然エネルギーの有効性の検証を長期計測データの解析に より行った。

床暖房十エアコン運転、パネル十床暖房＋エアコン運転、パネル のみ運転時の C O P、P MV S E T*をほぼ等しい外気条件下で 加熱熱量、電力量、気温、湿度、気流、放射熱から求め比較した。 短期データによると、エアコン、床暖房及びパネル暖房ではＣＯP が大きく異なり、1.7、1.0 及び $10 〜 16$ の数值を示している。パネ
ル暖房の C O P が大きいのは、熱量の製造を自然エネルギーに依存 していることと、電気エネルギーに依存しているのは、太陽熱集熱 系統とパネル循環系統のポンプのみであることによる。このことは、 室内の負荷状況によりパネルからの放熱量が増減するが、ポンプ動 力が変化しないため、負荷の大きい時は C O P が大きくなり、負荷 の小さい時はC O P が小さくなる特異な状況を作っている。

快適性に関しては、空気を直接加熱するエアコン暖房により室内 上部（F. $\mathrm{L}+1,500$ 以上）の空気温度が上昇し垂直温度分布が不均 一になること及びグローブ温度の指示值に天井パネル暖房の放射の 影響が顕著に現れ、低い室内空気温度で暖かく感じられることを考 えると、エアコン暖房主体よりも放射暖房主体にした方が快適性が 増すと考えられる。

冬期 2 シーズンの長期データから太陽集熱量、各暖房方式での寄 与率と太陽熱依存率を求め、各設定温度を変化させた時の運転状況 と照らし合わせた。その結果、エアコンの設定温度を $21^{\circ} \mathrm{C}$ 程度、床 暖房を $22^{\circ} \mathrm{C}$ 程度、パネルを $23^{\circ} \mathrm{C}$ 程度にすることが望ましいことが分 かった。表 5 から自然エネルギー依存率は平均で $23 \%$ であ、制御 の方法や状態により、さらに依存率が高くなることも考えられる。

各暖房方式の $\mathrm{CO}_{2}$ 排出量 $\left(\mathrm{kgCO}_{2} /\right.$ 月 $)$ を図 37 に示す。これにより、 $\mathrm{CO}_{2}$ 排出量が最大の方式は電気式床暖房で、最小は天井パネル + エア コン方式である。環境保護から天井パネル＋エアコンが望まれる。

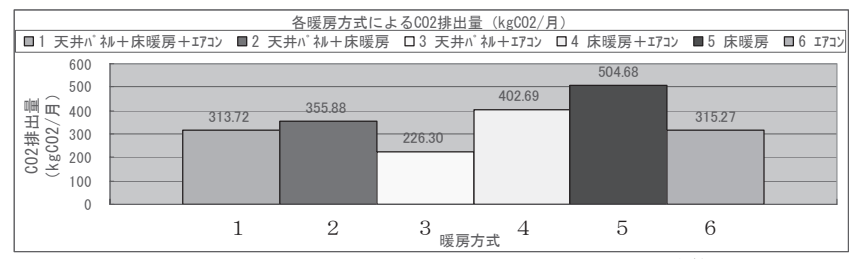

図 37 各暖房方式による $\mathrm{CO}_{2}$ 排出量 注 : $\mathrm{C} 02$ 排出量の換算係数は、環境省 $0.391[\mathrm{kgC02} / \mathrm{kWh}]$ を採用

\section{参考文献}

1）世良伸彦，武田仁，瀬沼央：天井輻射冷暖房システムの開発（その 4 水 熱媒暖房システムの構築と従来システムとの比較), 日本建築学会大会学 術講演梗概集 (関東), D 分冊, pp. 1691 1692, 1993.9

2) 片柳真介, 武田仁, 瀬沼央, 濱野卓哉: 天井輻射冷暖房システムの開発 (そ の 13 天井輻射暖房実験および室内温熱環境数值解析), 日本建築学会大 会学術講演梗概集 (近畿), D-2 分冊, pp. 843〜844, 1996.9

3）瀬沼央, 武田仁 : 放射冷暖房システムに関する研究（第 1 報一水熱媒冷暖 房システムの構築と従来システムとの比較), 空気調和・衛生工学会論文 集, No. 73 , pp. $57 \sim 63,1999.4$

4）宮永俊之，中野幸夫 : 放射冷房による居住熱環境の改善に関寸る研究（第 1 報一遮へいを考慮した形態係数の高精度計算法と熱環境解析への応用)， 日本建築学会計画系論文集，第 518 号，pp. 37〜44，1999. 4

5）宮永俊之, 占部亘, 中野幸夫, 梅干野晃 : 放射冷房による居住熱環境の改 善に関する研究（第 2 報一熱放射環境評価のための居室者の簡易型モデ ル)，日本建築学会計画系論文集，第 526 号，pp. 51〜 58, 1999.12

6) 李小平, 奥宮正哉: 太陽熱利用床暖房システムに関する研究, 日本建築学 会計画系論文集，第 539 号，pp. 29～36，2001.1

7）咸哲俊, 須永修通, 堀祐治 : 水蓄放熱床をもつ太陽熱床暖房システムに関 する実験研究，日本建築学会環境系論文集，第 572 号, pp. 39 45, 2003. 10

8）武田仁, 山本未生 : 井戸水利用天井放射冷暖房の有効性と被験者実験によ る快適性の評価, 日本建築学会計画系論文集, 第 550 号, pp. 31〜 37, 2001. 12

9）深井一夫 : 標準新有効温度 $\left(\mathrm{SE} \mathrm{T}^{*}\right)$ における放射, 湿度, 気流, 着衣 の影響の温度換算, 日本建築学会計画系論文報告集, 第 465 号, pp. 19〜 26, 1994. 11 